JOURNAL OF ISLAMIC EDUCATION

Vol. 6 No. I May 202 I

P-ISSN 2503-5363; E-ISSN 2528-0465

http://www.ejournal.stitmuhbangil.ac.id/index.php/jie

\title{
Pengembangan Sumber Daya Manusia dalam Meningkatkan Kualitas Kinerja Tenaga Pendidik dan Kependidikan di SMA Muhammadiyah 1 Ponorogo
}

\author{
* Novita Kusuma Hardaning ${ }^{1}$, Fata Asyrofi Yahya ${ }^{2}$ \\ 1,2(Institut Agama Islam Negeri (IAIN) Ponorogo, Jl Pramuka, No.156, Ponorogo) \\ noviita50@gmail.com
}

\begin{tabular}{ll}
\hline Informasi Artikel & Abstract \\
\hline Received: & This research discusses the development of \\
& educators and education staff which aims to \\
& determine the quality of performance carried out
\end{tabular}

Accepted: whether it has increased or not. Schools need to develop educators and education personnel to

Published: improve quality and ability through development activities such as training, career development, and motivation so that the success of human

Keywords:

Human Resources

Development, Quality of Performance resource development can be determined. This research uses a case study approach with qualitative research, the methods used are interviews, observation, and the use of documents as data collection. The results of the research show that the form of development that has been carried out by the school is by providing various training that has been planned, then through gradual career development planning and in accordance with the tenure, and through providing motivation to all human resources. Then the success of the development can be seen through improving the performance of each human resource, through performance appraisals carried out by the principal and his representatives and paying attention to predetermined performance indicators.

\section{PENDAhUluan}

Indonesia adalah Negara yang beraneka ragam dengan kebudayaanya. Indonesia juga merupakan Negara yang dikenal sebagai Negara yang kaya 
raya, namun dari segi sumber daya manusia masih sangat rendah, salah satunya dalam hal pendidikan. Pendidikan di Indonesia merupakan aspek yang sangat penting untuk mencerdaskan bangsa, sehinga untuk saat ini memerlukan banyak evaluasi dan peningkatan yang sistematis (Heni, 2020). Adanya perkembangan zaman yang semakin kompleks, maka diperlukan peningkatan kompetensi agar semakin menguasai bidang yang sesuai dengan keahliannya.

Perlu diketahui bahwa para guru dan karyawan memerlukan pelatihan tentang berbagai segi tugas yang dipercayakan kepada mereka, apalagi jika terdapat guru maupun karyawan baru pasti masih memerlukan sekali adaptasi maupun pengenalan awal terhadap kondisi sekolah serta mengikuti pelatihan mengenai tugas yang akan diemban. Para guru dan karyawan yang sudah berpengalaman pasti memerlukan peningkatan pengetahuan, keterampilan dan kemampuan karena selalu ada cara yang lebih baik untuk meningkatkan produktivitas kerja (Siagian, 2017).

Pengembangan sumber daya manusia adalah fungsi manajemen sumber daya manusia yang utama, tidak hanya pengembangan dan pelatihan, tetapi juga perencanaan karir individual, pemberian motivasi kepada setiap seluruh komponen sekolah, penilaian kinerja, dan suatu lembaga sekolah yang menekankan kebutuhan pelatihan dan pengembangan. Pelatihan dirancang untuk memberikan pengetahuan dan keterampilan yang dibutuhkan untuk kerja mereka di masa sekarang dan masa mendatang (Lijan, 2017). Kepuasan kerja karyawan adalah suatu fenomena yang perlu dicermati oleh pimpinan lembaga sekolah. Kepuasan kerja karyawan berhubungan erat dengan kinerja karyawan yang bersangkutan. Seseorang yang puas dalam pekerjaannya akan memiliki 
motivasi, komitmen pada lembaga sekolah, dan partisipasi kerja yang tinggi, sehingga akan terus memperbaiki kinerja mereka (Heryati and Muhsin, 2014).

Sumber daya manusia menjadi hal yang dominan pada suatu institusi, salah satunya pada bidang pendidikan. Pendidikan memerlukan sumber daya manusia yang berkualitas untuk melaksanakan peran dan tugasnya pada suatu lembaga dengan melayani kebutuhan masyarakat, maka diperlukan sumber daya manusia yang memiliki kualitas, keterampilan, mampu bersaing dan mampu bekerja sama. Pernyataan tersebut berhubungan adanya upaya pengembangan sumber daya manusia bagi terwujudnya tenaga kerja yang berkualitas di bidang pendidikan. Salah satu sekolah yang menjadi tempat penelitian yaitu SMA Muhammadiyah 1 Ponorogo. Sekolah telah memiliki program tahunan yang termasuk dalam upaya pengembangan SDM, untuk direncanakan dan nantinya akan direalisasikan menyesuaikan dengan kebutuhan sekolah. Hal yang sangat mendukung yaitu guru dan tenaga kependidikan rata-rata lulusan sarjana, ada sebagian yang telah mencapai tingkatan Magister, sehingga dengan adanya SDM yang memiliki tingkat pendidikan tinggi kemungkinan besar upaya dalam melakukan pengembangan SDM akan berhasil dan mengalami peningkatan kinerja.

Membaca keadaan dan menantang perkembangan jaman, maka setiap lembaga sekolah harus mampu aktif dengan mempertahankan kualitas sekolah, dengan pemikiran bahwa dengan dilakukannya pengembangan terhadap sumber daya manusia di sekolah maka akan menghasilkan SDM yang berkualitas dan memiliki daya saing. Berangkat dari keadaan ini, peneliti bermaksud untuk membahas mengenai bentuk pengembangan SDM dalam meningkatkan kualitas kinerja tenaga pendidik dan kependidikan di SMA Muhammadiyah 1 Ponorogo, dengan harapan mampu mengetahui keberhasilan 
dalam meningkatkan kinerja SDM dan dapat menjadi acuan bagi sekolah yang mengalami keterpurukan.

\section{METODE PENELITIAN}

Penelitian ini menggunakan jenis penelitian kualitatif yang menggunakan latar belakang alamiah dengan menafsirkan fenomena yang terjadi dan dengan melibatkan metode yang ada (Moleong, 2007). Untuk jenis pendekatan menggunakan studi kasus dengan memperhatikan semua aspek yang penting dari suatu kasus yang diteliti (Yusuf, 2016).

Lokasi penelitian yang dipilih adalah SMA Muhammadiyah 1 Ponorogo, beralamat di Jl. Batoro Katong 6 B, Nologaten, Ponorogo Jawa Timur.Sumber data dalam penelitian ini yaitu wakasek humas dan SDM, wakasek kurikulum, wakasek sarana prasarana, wakasek kesiswaan, KTU, dan beberapa guru di SMA Muhammadiyah 1 Ponorogo. Metode pengumpulan data menggunakan observasi, wawancara, dan dokumen. Sementara analisis data mencakup, reduksi data, display data, dan penarikan kesimpulan.

\section{TEMUAN DAN PEMBAHASAN}

\section{Konsep Pengembangan Sumber Daya Manusia}

Pengembangan sumber daya manusia merupakan langkah kelanjutan dari proses penyediaan tenaga kerja yang memiliki tujuan untuk memastikan, memelihara tenaga kerja yang tersedia dan tetap memenuhi kualifikasi yang dipersyaratkan oleh setiap institusi yang bersangkutan sehingga mampu selaras dengan perencanaan strategis, serta tujuan dapat tercapai sebagaimana yang telah direncanakan (Masram dan Muah, 2017). Pengembangan sumber daya manusia adalah penyiapan manusia atau tenaga kerja untuk memikul tanggung 
jawab lebih tinggi dalam lembaga maupun organisasi. Pengembangan sumber daya manusia berhubungan erat dengan usaha untuk meningkatkan kemampuan teknis, teoritis, konseptual, dan moral sesuai dengan kebutuhan yang diperlukan untuk melaksanakan pekerjaan yang lebih baik lagi (Anwar, 2021). Pengembangan sumber daya manusia juga membantu para tenaga kerja untuk mempersiapkan diri dalam menghadapi perubahan pekerjaan atau jabatan yang diakibatkan oleh adanya perkembangan zaman maupun teknologi baru yang semakin canggih.

Tujuan pokok pengembangan sumber daya manusia adalah meningkatkan kemampuan, keterampilan, sikap, dan tanggung jawab sehingga lebih efektif dan efisien dalam mencapai sasaran program dan tujuan dari lembaga maupun organisasi. Sehingga, dapat disimpulkan bahwa tujuan pengembangan sumber daya manusia adalah untuk memperbaiki efektivitas dan meningkatkan produktivitas kerja sumber daya manusia dalam melaksanakan dan mencapai sasaran yang telah ditentukan (Samsudin, 2006).

Sedangkan bentuk-bentuk pengembangan SDM dapat dilakukan dengan berbagai cara berikut ini:

\section{Pemberian Pelatihan}

Pelatihan merupakan kegiatan yang terarah, serta harus mempunyai sasaran yang jelas dengan memuat hasil yang ingin dicapai dalam melaksanakan kegiatan tersebut (Taufiqurokhman, 2009). Menurut Andrew F. Sikula, pemberian pelatihan atau training dapat dilakukan dengan beberapa cara, diantaranya: (a) On the job, atau pelatihan dalam jabatan, merupakan teknik pelatihan di mana para peserta pelatiha dilatih langsung di tempat ia bekerja. Cara pelatihannya dibedakan dalam dua cara, yang pertama cara informal, yaitu pelatih menyuruh peserta untuk memperhatikan orang lain yang 
sedang melakukan pekerjaan, kemudian ia diperintahkan untuk mempraktekkannya. Kedua, cara formal yaitu pelatih menunjuk senior maupun yang sudah berpengalaman untuk melakukan suatu pekerjaan, selanjutnya peserta pelatihan melakukan pekerjaan sesuai dengan cara-cara yang telah dilakukan oleh senior. (b) Vestibule merupakan pelatihan yang dilakukan dalam kelas untuk memperkenalkan pekerjaan kepada tenaga kerja baru dan melatih mereka dalam mengerjakan pekerjaan yang menjadi bidangnya masing-masing. (c) Demonstration and example, merupakan pelatihan yang dilakukan dengan cara peragaan dan penjelasan mengenai bagaimana cara mengerjakan sesuatu pekerjaan melalui contoh-contoh atau pekerjaan yang didemonstrasikan. (d) Simulation atau simulasi merupakan situasi atau kejadian yang ditampilkan semirip mungkin dengan situasi yang sebenarnya tapi hanya tiruan saja untuk memberi pemahaman kepada tenaga kerja (Hasibuan and Hasibuan 2016). (e) Classroom methods, dirancang dalam bentuk pembelajaran di dalam kelas dengan menggunakan metode ceramah diskusi. Akivitas pembelajaran pada umumnya berjalan sepihak, instruktur aktif memberi informasi atau pengetahuan kepada peserta. (f) Off the job training, diselenggarakan di lokasi yang terpisah. Program pelatihan ini memberikan kepada individu, mengenai keahlian dan pengetahuan yang mereka butuhkan untuk mengerjakan pekerjaan pada waktu yang terpisah dari waktu kerja regular mereka (Rahmi and Suryalena, 2017).

\section{Perencanaan dan Pengembangan Karier}

Karier dapat diartikan sebagai perjalanan pekerjaan (riwayat kerja) seseorang di dalam suatu lembaga maupun organisasi, mulai ia diterima sebagai anggota baru dan berakhir pada saat ia tidak bekerja lagi (Ulfatin and Triwiyanto, 2016). Berikut pemaparan mengenai perencanaan dan 
pengembangan karier. Perencanaan karier adalah suatu perencanaan tentang kemungkinan para anggota suatu lembaga sebagai individu yang menempuh proses kenaikan pangkat atau jabatan sesuai persyaratan dan kemampuannya. Keberhasilan karir seseorang dipengaruhi oleh beberapa hal, antara lain yaitu pendidikan formal, pengalaman kerja, sikap dari atasan, memiliki prestasi kerja, bobot pekerjaan, lowongan jabatan, dan produktivitas kerja.

Dalam perencanaan karier diperlukan beberapa hal pokok yaitu: (a) Jabatan pokok dan jabatan penunjang. Jabatan pokok adalah jabatan dengan tupoksi menunjang langsung tercapainya sasaran pokok suatu lembaga, sedangkan jabatan penunjang adalah jabatan dengan tupoksi menunjang tercapainya sasaran pokok suatu lembaga. (b) Pola jalur karier bertahap, merupakan pola yang menunjukkan urutan berjenjang dan bertahap dari jabatan-jabatan yang tersusun dalam struktur organisasi. (c) Jabatan struktural, merupakan jabatan yang diperuntukkan bagi tenaga kerja untuk diarahkan ke jenjang yang paling tinggi dalam suatu lembaga, dan (d) Tenggang waktu jabatan atau masa jabatan seseorang dalam suatu lembaga sebaiknya ditentukan secara tegas dan pasti, karena hal tersebut akan memberikan dampak psikologis yang positif terhadap pemangku jabatan yang bersangkutan (Samsudin, 2006).

Adapun pengembangan karier yaitu proses yang akan dilalui oleh anggota suatu lembaga dengan serangkaian tahapan, aktivitas dan hubungan yang berbeda. Secara garis besar terdapat dua pendekatan terhadap model pengembangan karier yaitu: (a) Model tradisional. Pada model pengembangan karier tradisional terdapat beberapa tahapan, yaitu exploration (mengidentifikasi jenis pekerjaan yang menarik minat mereka dan kesesuaian antara dirinya dengan pekerjaan), estabilishment (pembentukan di mana 
individu telah mendapatkan tempatnya dalam suatu lembaga), maintance (pemeliharaan terhadap keterampilan yang dimiliki), dan disengagement (pelepasan yang akan memasuki masa pensiun dan anggota senior lebih senang mengurangi jam kerjanya secara bertahap), dan (b) Model kontemporer. Pandangan kontemporer mengenai pengembangan karier, bahwa tenaga kerja dan lembaga seyogyanya fleksibel dan dapat beradaptasi agar tetap stabil dan mampu bersaing dalam lingkungan yang terus menerus berubah dan tidak menentu, artinya dibutuhkan fleksibilitas dalam melakukan penyesuaian karier (Sinambela, 2017).

\section{Pemberian Motivasi}

Motivasi adalah proses atau kegiatan mempengaruhi/ memberi dorongan dari luar terhadap seseorang atau kelompok kerja agar mereka mau melaksanakan sesuatu yang telah ditetapkan. Jadi, motivasi kerja adalah sesuatu yang menimbulkan dorongan atau semangat kerja. Beberapa faktor yang mempengaruhi motivasi kerja antara lain atasan, kolega, sarana fisik, kebijaksanaan, peraturan, imbalan jasa uang dan non uang, jenis pekerjaan dan tantangan (Samsudin, 2006).

Berikut terdapat beberapa model motivasi yaitu: (a) Model tradisional, merupakan model dengan para pimpinan memberikan dorongan atau memotivasi tenaga kerja dengan cara memberikan imbalan berupa gaji/ upah yang makin meningkat, (b) Model hubungan manusiawi, merupakan model dengan para pimpinan memotivasi karyawan dengan memenuhi kebutuhan sosial mereka dan membuat mereka merasa penting dan berguna, dan (c) Model sumber daya manusia, merupakan model dengan meningkatkan tanggung jawab bersama untuk mencapai tujuan suatu lembaga dengan cara 
setiap anggota menyumbangkan sesuatu kepada lembaga sesuai dengan kepentingan dan kemampuan anggota masing-masing (Samsudin, 2006).

\section{Kinerja Tenaga Pendidik dan Kependidikan}

Kinerja (performance) adalah gambaran mengenai tingkat pencapaian pelaksanaan suatu kegiatan/ program/ kebijakan dalam mewujudkan sasaran, tujuan, misi, dan visi lembaga. Istilah kinerja sering digunakan untuk menyebut prestasi atau tingkat keberhasilan individu maupun kelompok individu (Mariana, 2012). Kinerja merupakan hasil kerja/ hasil usaha yang dilakukan oleh setiap individu untuk membuktikan bahwa hal-hal yang dilakukan dapat membuahkan hasil yang telah ditargetkan sebelumnya.

Dalam konteks penelitian ini, untuk mengukur kinerja tenaga pendidik dan kependidikan, maka harus dijelaskan dahulu terkait dengan tugas tenaga pendidik dan kependidikan. Pertama, tugas pendidik, sebagaimana dijelaskan dalam UU Sistem Pendidikan Nasional No 20 Tahun 2003 Pasal 39 ayat 2, bahwa pendidik merupakan tenaga professional yang bertugas merencanakan dan melaksanakan proses pembelajaran, menilai hasil pembelajaran, melakukan pembimbingan dan pelatihan, serta melakukan penelitian dan mengabdi pada masyarakat, terutama bagi pendidik pada perguruan tinggi (Rusi, 2018). Guru jelas adalah pendidik. Dalam Rancangan Peraturan Pemerintah (RPP) BAB XII, tahun 2005 Pasal 139, Pasal 1 dinyatakan bahwa pendidik mencakup guru, dosen, konselor, pamong belajar, pamong widyaiswara, tutor, instruktur, fasilitator, pelatih, dan sebutan lain dari profesi yang berfungsi sebagai agen pembelajaran peserta didik. Untuk menjadi pendidik yang profesional, haruslah memiliki kompetensi keahlian dasar sebagai tenaga pendidik. Sebagaimana dinyatakan dalam standar tenaga pendidik dan tenaga kependidikan bahwa 
tenaga pendidik menurut PP No. 19/2005, BAB VI Pasal 28 tentang standarisasi tenaga pendidik.

Kedua, tenaga kependidikan, sebagiamana dinyatakan di dalam pasal 140 ayat 1 (Rancangan Peraturan Pemerintah, BAB XII/ 2005) sebagai berikut. Tenaga kependidikan mencakup pimpinan satuan pendidikan, pemilik satuan pendidikan non formal, pengawas satuan pendidikan formal, tenaga perpustakaan, tenaga laboratorium, teknisi sumber belajar, tenaga lapangan pendidikan, tenaga administrasi, psikolog, pekerja sosial, terapis, tenaga kebersihan sekolah, dan sebutan lain untuk petugas sejenis yang bekerja pada satuan pendidikan (Bachtiar 2016). Tugas pokok tenaga kependidikan tertuang dalam Undang-Undang Sistem Pendidikan Nasional Nomor 20 tahun 2003 BAB XI Pasal 39 ayat 1 yang menyebutkan, "Tenaga kependidikan bertugas melaksanakan administrasi, pengelolaan, pengembangan, pengawasan, dan pelayanan teknis untuk menunjang proses pendidikan pada satuan pendidikan." Tugas pokok ini masih perlu diperjelas sesuai dengan tenaga kependidikan masing-masing (Hamid, 2013).

Untuk mengetahui kualitas dari tenaga pendidik dan kependidikan, maka perlu dilakukan pengukuran dan penilaian terhadap kinerja mereka. Pengukuran kinerja (performance measurement) merupakan proses penilaian kemajuan pekerjaan terhadap tujuan dan sasaran yang telah ditentukan sebelumnya. Pengukuran kinerja adalah suatu metode atau alat yang digunakan untuk mencatat dan menilai pencapaian pelaksanaan kegiatan berdasarkan tujuan, sasaran, dan strategi sehingga dapat diketahui kemajuan lembaga atau organisasi serta dapat meningkatkan kualitas pengambilan keputusan dan akuntabilitas (Kristiyanti, 2012). 
Kinerja pegawai berpengaruh signifikan terhadap pertumbuhan lembaga maupun organisasi. Oleh karena itu, untuk mengetahui kinerja pegawai perlu dilakukan penilaian kinerja yang teratur dan sistematis yang bisa dilakukan dengan beberapa cara berikut:

1. Penilaian kinerja dengan metode tradisional, adalah metode yang digunakan oleh kepala sekolah/ pimpinan dengan berusaha memilih prosedur manajerial yang akan meminimumkan konflik dengan orang yang sedang dinilai, dan membantu tercapainya tujuan lembaga. Pimpinan berusaha menemukan, mengembangkan, dan melaksanakan program penilaian kinerja yang dapat bermanfaat bagi para tenaga kerja.

2. Metode pemangkatan atau peringkat, metode ini dikenal dengan penilaian ranking. Mengenai prosedur biasanya mencakup pengenalan orang yang paling baik dan buruk kinerjanya. Penyusunan urutan pangkat ini berlangsung terus-menerus hingga semua pegawai ditempatkan pada daftar pemangkatan.

3. Pembobotan checklist, penilaian berdasarkan checklist yang dibobot terdiri dari jumlah pernyataan yang menjelaskan beraneka macam dan tingkat perilaku bagi suatu pekerjaan tertentu atau bagi sekelompok pekerjaan tertentu (Sinambela, 2017).

\section{pengembangan SDM dalam meningkatkan kualitas kinerja tenaga pendidik dan kependidikan di SMA Muhammadiyah 1 Ponorogo}

Pengembangan sumber daya manusia merupakan kegiatan yang sistematis dan terencana yang dirancang untuk memfasilitasi para guru dan karyawan agar kecakapan yang dibutuhkan dapat memenuhi tuntutan pekerjaan, baik pada saat ini maupun pada masa mendatang (Ahmad Mujaddid, et al. 2019). Adapun pengembangan sumber daya manusia yang berkaitan 
dengan upaya meningkatkan pengetahuan, kemampuan maupun sikap dan keahlian para guru dan karyawan di SMA Muhammadiyah 1 Ponorogo dengan menyelenggarakan berbagai pelatihan, penyediaan jalur karier guru dan karyawan serta pemberian motivasi terhadap seluruh warga sekolah dengan partisipasi positif untuk dapat mewujudkan tujuan sekolah.

\section{Pemberian Pelatihan}

Pelatihan diperlukan bagi sumber daya manusia sebagai upaya untuk mempersiapkan diri yang siap untuk menghadapi pekerjaan yang dianggap belum dikuasai oleh setiap individu. Langkah tersebut dilakukan untuk menghindari kemungkinan terburuk dalam tanggung jawab dalam bekerja sehingga sumber daya manusia ataupun tenaga kerja dapat menyelesaikan pekerjaan dengan lebih efektif dan efisien yang akan memberikan dampak baik bagi lembaga sekolah (Lenny, $\mathrm{tt}$ ).

Hasil setelah melakukan penelitian di SMA Muhammadiyah 1 Ponorogo, dapat diketahui pelatihan-pelatihan yang dilakukan di antaranya ada sinergi Building, Quantum Learning, workshop e-learning, baitul arqom, pelatihan menuju sekolah SKS, MGMP internal dan eksternal (wawancara, Yayuk). Pelatihan dilakukan di sekolah dan di luar sekolah dengan mempertimbangkan berbagai situasi dan keadaan. Beberapa bentuk pelatihan di atas sesuai dengan bentuk-bentuk pelatihan dalam pengembangan SDM menurut Andrew F. Sikula, dimana bentuk-bentuk pemberian pelatihannya ada beberapa cara sebagai berikut:

Pertama, on the job training merupakan pelatihan yang dilakukan dengan para perserta dilatih langsung di tempat bekerja. Pelatihan yang termasuk on the job training pada SMA Muhammadiyah 1 Ponorogo adalah pelatihan menuju sekolah SKS, di mana pelatihan tersebut memiliki manfaat bagi para siswa yang 
menginginkan cepat lulus, kemudian baitul arqom, yaitu kegiatan yang dilaksanakan untuk guru dan karyawan oleh majelis pendidikan kader muhammadiyah ponorogo.

Kedua, vestibule merupakan pelatihan yang dilakukan dalam kelas untuk memperkenalkan pekerjaan kepada tenaga kerja baru maupun tenaga kerja lama dan melatih mereka dalam mengerjakan pekerjaan yang menjadi bidangnya. Pelatihan yang termasuk vestibule pada SMA Muhammadiyah 1 Ponorogo adalah workshop e-learning, di mana workshop tersebut diadakan untuk melatih para guru dan tenaga kependidikan mampu mempelajari dan menggunakan teknologi untuk pembelajaran dan teknis pengelolaan sekolah bagi tenaga kependidikan.

Ketiga, Demontstration and example merupakan pelatihan yang efektif, karena peserta pelatihan melihat sendiri teknik mengerjakannya dan diberikan penjelasan, bahkan jika diperlukan perserta pelatihan boleh mempraktekkannya. Pelatihan yang termasuk demontstration and example pada SMA Muhammadiyah 1 ponorogo adalah quantum learning yang memiliki tujuan agar para guru memiliki dinamika dalam mengajar.

Keempat, off the job training diselenggarakan di lokasi yang terpisah. Program pelatihan tersebut mengenai keahlian dan pengetahuan yang dibutuhkan untuk mengerjakan pekerjaan pada waktu yang terpisah dari waktu kerja regular masing-masing tenaga kerja. Pelatihan yang termasuk off the job training pada SMA Muhammadiyah 1 Ponorogo adalah sinergi building, yaitu untuk merefreshing serta melatih kebersamaan dan keakraban anggota, semua dianggap sama agar timbul semangat kerja. 


\section{Perencanaan dan pengembangan karier}

Cara yang dapat ditempuh dalam melakukan pengembangan karier terhadap sumber daya manusia di sekolah yaitu dengan meciptakan situasi dan kondisi yang mendukung, memungkinkan sumber daya manusia yang ada dapat mencapai jenjang kariernya dengan tepat waktu sesuai dengan peraturan yang berlaku (Hermawan, 2010).

Hasil yang didapat setelah melakukan penelitian bahwa di SMA Muhammadiyah 1 Ponorogo dalam melakukan perencanaan karier menggunakan pola karier bertahap maupun berjenjang sesuai dengan waktu dalam masa bekerja, kemudian memasuki jabatan struktural yang diperuntukkan bagi SDM untuk mengarah ke jenjang yang lebih tinggi lagi dalam jabatan di sekolah, dengan melakukan orientasi dan melihat kemampuan setiap individu (wawancara, Sachrur).

Sedangkan untuk pengembangan kariernya, SMA Muhammadiyah 1 Ponorogo memberi peluang untuk SDM mengembangkan diri sebaik mungkin dengan belajar dan belajar lagi, menempuh pendidikan lebih lanjut atas persetujuan sekolah (wawancara, Yayuk), serta mampu melatih keahlian yang sesuai dengan pekerjaan yang dilakukan di sekolah, serta dapat memberikan inovasi bagi perbaikan sekolah kedepannya.

\section{Pemberian motivasi}

Motivasi merupakan dorongan yang timbul dari dalam diri maupun dorongan orang lain. Salah satu hal pendukung keberhasilan lembaga sekolah dalam mencapai tujuannya adalah motivasi. Motivasi kerja guru dan pegawai dapat mempengaruhi keberhasilan dalam mencapai suatu tujuan yang telah dirumuskan oleh lembaga sekolah. Motivasi kerja mempersoalkan bagaimana 
cara untuk mendorong semangat kerja masing-masing guru dan karyawan, agar mereka mau bekerja keras.

Kesimpulan yang di dapat dari hasil penelitian bahwa SMA Muhammadiyah 1 Ponorogo selalu memberikan motivasi kepada seluruh SDM sekolah dengan pendekatan, pemberian masukan, saling mengingatkan tugas pokok dan fungsi, dengan begitu setiap pribadi individu akan merasa diperhatikan dan dapat menjadi evaluasi diri untuk meningkatkan kinerja maupun keahlian yang dimiliki (wawancara, Sachrur). Dalam pemberian motivasi tidak selalu dilakukan oleh kepala sekolah, karena kepala sekolah juga memiliki kesibukan yang padat, sehingga rekan sejawat maupun wakasek beserta bapak ibu yang sudah senior di SMA Muhammadiyah 1 Ponorogo juga memiliki pengaruh untuk memberikan motivasi terhadap sesama rekan kerjanya.

\section{Keberhasilan pengembangan SDM dalam meningkatkan kualitas kinerja tenaga pendidik dan kependidikan di SMA Muhammadiyah 1 Ponorogo}

Tuntutan era globalisasi menempatkan pentingnya upaya peningkatan kualitas pendidikan melalui sekolah sebagai sarana dalam membangun dan membentuk kualitas sumber daya manusia (Amran, 2015). Sekolah yang bisa dikatakan berhasil, adalah sekolah yang menunjukkan tingkat kesesuaian antara hasil yang di capai dengan hasil yang diharapkan sebagaimana telah memenuhi tuntutan maupun aturan dari sekolah dan mampu mengembangkan potensi diri dengan baik.

Kinerja merupakan perwujudan dari kemampuan maupun kecakapan dalam bentuk karya nyata. Kinerja kaitannya dengan jabatan, diartikan sebagai hasil yang dicapai yang berkaitan dengan fungsi jabatan dalam periode waktu tertentu (Madjid, 2016). Sehingga dapat disimpulkan bahwa kinerja adalah 
sesuatu yang ingin dicapai, prestasi yang diperlihatkan, serta kemampuan dalam bekerja, baik tenaga pendidik maupun kependidikan. Mengetahui perkembangan salah satu sekolah swasta dari sekian banyak sekolah di wilayah Ponorogo, yaitu SMA Muhammadiyah 1 Ponorogo memiliki prestasi dan reputasi, baik dari berbagai prestasi yang di raih oleh lembaga sekolah sendiri, kemudian prestasi dari para guru dan prestasi dari siswa di bidang akademik dan non akademik. Berikut merupakan beberapa cara untuk mengetahui keberhasilan dari pengembangan terhadap sumber daya manusia yang telah dilaksanakan oleh pihak sekolah yang bersangkutan.

\section{Peningkatan kinerja sumber daya manusia}

Peningkatan kualitas kinerja dari masing-masing tenaga pendidik dan kependidikan dipengaruhi oleh pengembangan SDM yang diaplikasikan dengan memberikan pelatihan, perencanaan dan pengembangan karier, serta pemberian motivasi terhadap SDM di sekolah. Terdapat indikator pendukung dalam menentukan keberhasilan pengembangan yang telah direncanakan sebelumnya, dapat diuraikan dalam tabel berikut:

Tabel 1. Indikator keberhasilan pengembangan SDM

\begin{tabular}{|c|c|c|}
\hline No & $\begin{array}{c}\text { Pengembangan SDM } \\
\text { yang dilakukan Sekolah }\end{array}$ & Indikator keberhasilan \\
\hline 1 & $\begin{array}{l}\text { Pemberian pelatihan: } \\
\text { a. Sinergi building } \\
\text { b. Training quantum } \\
\text { c. Workshop E-learning } \\
\text { d. Baitul Arqom } \\
\text { e. Pelatihan mengenai } \\
\text { sekolah SKS }\end{array}$ & $\begin{array}{l}\text { a. Pembelajaran semakin aktif } \\
\text { b. Menguasai materi yang akan di } \\
\text { terapkan di kelas } \\
\text { c. Memiliki inisiatif dalam bekerja } \\
\text { d. Mampu memberikan kontribusi } \\
\text { berupa tenaga maupun } \\
\text { pengetahuan setelah mengikuti }\end{array}$ \\
\hline
\end{tabular}




\begin{tabular}{|c|c|c|}
\hline & $\begin{array}{l}\text { f. MGMP internal dan } \\
\text { Eksternal } \\
\text { g. Pelatihan mental }\end{array}$ & pelatihan \\
\hline 2 & $\begin{array}{l}\text { Perencanaan dan } \\
\text { pengembangan karier }\end{array}$ & $\begin{array}{l}\text { a. Memahami kemampuan dalam } \\
\text { melaksanakan pekerjaannya } \\
\text { sebagai tenaga pendidik maupun } \\
\text { kependidikan } \\
\text { b. Memberi kontribusi secara baik } \\
\text { untuk pengelolaan pendidikan } \\
\text { maupun pembelajaran di sekolah } \\
\text { c. Mampu mengembangkan } \\
\text { keprofesian yang dimiki }\end{array}$ \\
\hline 3 & Pemberian motivasi & $\begin{array}{l}\text { a. Tingkat kedisiplinan meningkat } \\
\text { b. Memiliki rasa tanggung jawab } \\
\text { yang tinggi terhadap } \\
\text { pekerjaannya } \\
\text { c. Mampu menerima kritik, saran } \\
\text { dan masukan } \\
\text { d. Melakukan perbaikan kinerja tiap } \\
\text { harinya }\end{array}$ \\
\hline
\end{tabular}

Berdasarkan hasil penelitian di SMA Muhammadiyah 1 Ponorogo, peneliti mengetahui bahwa kinerja setiap tenaga pendidik dan kependidikan mengalami peningkatan setiap semester. Peningkatan kinerja tersebut dipengaruhi dengan kegiatan pengembangan yang telah dilaksanakan oleh sekolah, seperti yang telah disinggung sebelumya, yaitu adanya pelatihan, pengembangan karier SDM, serta pemberian motivasi untuk lebih memberi energi positif dalam menjalankan tugas dan kewajiban yang sesuai dengan profesi setiap individu di 
sekolah. Sehingga tugas dari tenaga pendidik sebagai pengajar dan tenaga kependidikan yang melaksanakan kegiatan pelaksanaan pendidikan di sekolah akan terlaksana dengan sistematis dan terencana.

\section{Menentukan pengukuran dan penilaian kinerja}

Pengukuran kinerja merupakan suatu cara yang digunakan untuk menilai pelaksanaan kegiatan berdasarkan tujuan dan sasaran yang telah ditentukan sebelumnya. Ukuran kinerja juga mengacu pada penilaian kinerja tenaga pendidik dan kependidikan secara langsung (Kristiyanti, 2012).

Selain itu, dalam menentukan keberhasilan kinerja juga dapat ditentukan dengan dilakukannya penilaian kinerja. Selain itu, penilaian kinerja mempunyai tujuan, diantaranya adalah: (a) memberdayakan tingkat prestasi setiap SDM, (b) pengambilan keputusan administrasi seperti seleksi, promosi, demosi, dan (c) pemberian pinalti seperti, bimbingan untuk meningkatkan motivasi dan pelatihan untuk mengembangkan keahlian (Rahadi 2010). Berdasarkan hasil penelitian yang peneliti dapatkan, SMA Muhammadiyah 1 Ponorogo dalam melakukan penilaian kinerja dilakukan dengan cara:

Tabel 2. Bentuk penilaian kinerja

\begin{tabular}{|l|l|l|l|}
\hline No & \multicolumn{1}{|c|}{$\begin{array}{c}\text { Metode penilaian } \\
\text { kinerja }\end{array}$} & \multicolumn{1}{|c|}{$\begin{array}{c}\text { Pihak yang } \\
\text { menilai kinerja }\end{array}$} & $\begin{array}{c}\text { Sasaran } \\
\text { penilaian kinerja }\end{array}$ \\
\hline 1 & $\begin{array}{l}\text { Penilaian langsung dengan } \\
\text { pemantauan (secara } \\
\text { langsung di lapangan atau } \\
\text { bisa menggunakan cctv) }\end{array}$ & Kepala Sekolah & $\begin{array}{l}\text { Seluruh tenaga } \\
\text { pendidik dan } \\
\text { kependidikan }\end{array}$ \\
\hline 2 & $\begin{array}{l}\text { Checklis pada setiap } \\
\text { kegiatan sekolah }\end{array}$ & $\begin{array}{l}\text { Kepala sekolah } \\
\text { dibantu dengan } \\
\text { wakasek }\end{array}$ & $\begin{array}{l}\text { Seluruh tenaga } \\
\text { pendidik dan } \\
\text { kependidikan }\end{array}$ \\
\hline
\end{tabular}




\begin{tabular}{|l|l|l|l|}
\hline 3 & $\begin{array}{l}\text { Survey angket sebaran } \\
\text { kepada siswa }\end{array}$ & $\begin{array}{l}\text { Kepala sekolah } \\
\text { dibantu dengan } \\
\text { wakasek }\end{array}$ & $\begin{array}{l}\text { Guru yang } \\
\text { mengajar dalam } \\
\text { kelas }\end{array}$ \\
\hline 4 & Sidak langsung & Kepala sekolah & $\begin{array}{l}\text { Guru yang sedang } \\
\text { melakukan } \\
\text { pembelajaran }\end{array}$ \\
\hline
\end{tabular}

Oleh karena itu, setiap SDM yang bersangkutan perlu ditempatkan pada pekerjaan yang sesuai dengan keahliannya (the right man on the right place, the right man on the right job) (Akbar 2018). Mengenai hasil dilakukan penilaian kinerja di SMA Muhammadiyah 1 Ponorogo, yaitu sebagai berikut: (a) adanya semangat kerja, (b) semakin mengasah kemampuan dan keahlian, (c) memiliki inovasi untuk pembelajaran yang lebih baik, (d) muncul sikap kedisiplinan, tekun dan ulet dalam bekerja, (e) mampu berkomunikasi dengan baik, dan (f) kiat meningkatkan ilmu pengetahuan dan memiliki keterampilan, baik dalam hal mengajar maupun manajerial.

\section{Indikator kinerja}

Secara umum, kinerja sumber daya manusia dapat diukur dengan indikator-indikator sebagai berikut: (a) kualitas kerja, (b) kecepatan atau ketepatan kerja, (c) inisiatif dalam bekerja, (d) kemampuan bekerja, dan (e) komunikasi (Faizah 2019). Indikator tersebut dapat digunakan untuk mengetahui keberhasilan dari kinerja tenaga pendidik dan kependidikan.

Indikator untuk menilai kinerja tenaga pendidik khususnya pada bidang pendidikan dan pengajaran, antara lain dapat diketahui dari beberapa hal yaitu: (1) pembelajaran, (2) keterampilan, (3) penilaian dan beban kerja, (4) bimbingan konseling, dan (5) sumber pembelajaran. Sedangkan indikator untuk menilai kinerja tenaga kependidikan dalam hal pelayanan dapat diketahui dari 
beberapa hal yaitu: (1) tanggung jawab, (2) kualitas, (3) kuantitas, dan (4) disiplin (Mahfuzil, 2017).

\section{KESIMPULAN}

Bentuk pengembangan SDM dalam meningkatkan kualitas kinerja tenaga pendidik dan kependidikan SMA Muhammadiyah 1 Ponorogo dengan melakukan pengembangan terhadap sumber daya manusia secara menyeluruh. Berikut diantaranya yaitu: (1) Melalui pemberian pelatihan. Pelatihan tersebut dilakukan selama satu tahun sekali dengan memperhatikan kalender akademik sekolah. Mulai tahun pelajaran 2019-2020 sekolah telah melaksanakan beberapa pelatihan, diantaranya adalah: Sinergi Building, Quantum Teaching, Workshop E-learning, baitul arqom, pelatihan menuju sekolah SKS, MGMP internal dan Eksternal; (2) Melalui perencanaan pengembangan karier bertahap maupun berjenjang sesuai dengan waktu dalam masa bekerja; dan (3) Melalui pemberian motivasi kepada seluruh tenaga pendidik dan kependidikan di sekolah dengan tujuan meningkatkan semangat kerja.

Keberhasilan pengembangan SDM dalam meningkatkan kualitas kinerja tenaga pendidik dan kependidikan SMA Muhammadiyah 1 Ponorogo, dapat diketahui melalui pengembangan sumber daya manusia dan dapat diketahui melalui beberapa hal berikut ini: (1) peningkatan dari kinerja setiap sumber daya manusia salah satunya dapat diketahui melalui kegiatan pengembangan SDM yang dilakukan oleh pihak sekolah selama kurun waktu satu tahun sekali, (2) metode penilaian kinerja terhadap tenaga pendidik dan kependidikan yang dilakukan oleh kepala sekolah dengan wakilnya, dan (3) menentukan indikator kinerja untuk dapat mengukur sejauh mana kinerja yang sudah dicapai, apakah sudah memenuhi keinginan yang diharapkan sekolah atau belum. 


\section{BIBLIOGRAFI}

[1] Ahmad Mujaddid, et al. 2019. "Pengembangan Sumber Daya Manusia Dalam Pendidikan." Universitas Islam Negeri Alaudin, January.

[2] Akbar, Surya. 2018. "Analisa Faktor-Faktor Yang Mempengaruhi Kinerja Karyawan." JIAGANIS 3 (1).

[3] Aliyyah, Rusi Rusmiati. 2018. Pengelolaan Pendidik Dan Tenaga Kependidikan. Jakarta: Polimedia Publishing.

[4] Amran, Amran. 2015. "Faktor Penentu Keberhasilan Pengelolaan Satuan Pendidikan." Manajer Pendidikan 9 (2).

[5] Anwar, S. (2021). Internalisasi Nilai Pendidikan Akhlak dalam Surat AlHujurat Tafsir fi ZIlalil Qur'an. JIE: Journal of Islamic Edication, 6(1), 112.

[6] Bachtiar, Muhammad Yusri. 2016. "Pendidik Dan Tenaga Kependidikan." Publikasi Pendidikan 6 (3).

[7] Faizah, Umi. 2019. "Evaluasi Kinerja Pendidik Dan Tenaga Kependidikan Dan Proses Pembelajaran Pendidikan Islam Di Indonesia." Al-Fikri: Jurnal Studi Dan Penelitian Pendidikan Islam 2 (2): 44-54.

[8] Hamid, Hamdani. 2013. Pengembangan Sistem Pendidikan Di Indonesia. CV. Pustaka Setia.

[9] Hasibuan, Malayu SP, and H. Malayu SP Hasibuan. 2016. Manajemen Sumber Daya Manusia. Bumi Aksara.

[10] Heni Akhwat Damanik. 2020. "Sistem Pendidikan Indonesia, Antara Masalah Dan Solusi!" Kompasiana.Com, January 17, 2020.

[11] Hermawan, Ruswandi. 2010. "Pengembangan Sumber Daya Sekolah." Jurnal Pendidikan Dasar 2 (1): 68.

[12] Heryati, Yeti, and Mumuh Muhsin. 2014. Manajemen Sumber Daya Pendidikan. Bandung: CV Pustaka Setia.

[13] Kristiyanti, Mariana. 2012. "Peran Indikator Kinerja Dalam Mengukur Kinerja Manajemen." Majalah Ilmiah Informatika 3 (3).

[14] Lenny Hasan. n.d. "Konsep Pendidikan Dan Pelatihan Dalam Manajemen Sumber Daya Manusia." Fakultas Ekonomi Universitas Tamansiswa Padang. 
[15] Madjid, Abd. 2016. Pengembangan Kinerja Guru Melalui: Kompetensi, Komitmen Dan Motivasi Kerja. Yogyakarta: Samudra Biru.

[16] Mahfuzil, Anwar. 2017. "Analisis Kinerja Tenaga Pendidik Dan Kependidikan (Dosen Dan Karyawan) Pada STIMI Banjarmasin." Jurnal Riset Inspirasi Manajemen Dan Kewirausahaan 1 (2): 1-16.

[17] Masram dan Muah. 2017. Manajemen Sumber Daya Manusia Profesional. Surabaya: Zifatama Publisher.

[18] Moleong, Lexy J. 2007. Metode Penelitian Kualitatif. Bandung: Remaja Rosdakarya.

[19] Rahadi, Dedi Rianto. 2010. Manajemen Kinerja Sumber Daya Manusia. Malang: Tunggal Mandiri Publishing, 2010.

[20] Rahmi, Hidayatul, and Suryalena Suryalena. 2017. "Pengaruh On The Job Training Dan Off The Job Training Terhadap Kinerja Karyawan (Studi Pada Karyawan Bagian Kantor PTPN V Unit Kebun Lubuk Dalam Kabupaten Siak)." PhD Thesis, Riau University.

[21] Samsudin, Sadili, and M. Pd MM. 2006. Manajemen Sumber Daya Manusia, CV. Bandung: Pustaka Setia.

[22] Siagian, Sondang P. 2017. Manajemen Sumber Daya Manusia. Bumi Aksara.

[23] Sinambela, Lijan Poltak. 2017. Manajemen Sumber Daya Manusia. Bumi Aksara.

[24] Taufiqurokhman. 2009. Mengenal Manajemen Sumber Daya Manusia. Jakarta: Fakultas Ilmu Sosial dan Ilmu Politik Universitas Prof. Dr. Moestopo Beragama.

[25] Ulfatin, Nurul, and Teguh Triwiyanto. 2016. Manajemen Sumber Daya Manusia Bidang Pendidikan. Jakarta: Raja Wali Pers, .

[26] Yusuf, A. Muri. 2016. Metode Penelitian Kuantitatif, Kualitatif \& Penelitian Gabungan. Prenada Media. 